Jurnal e-Biomedik (eBM), Volume 1, Nomor 3, November 2013

\title{
PREVALENSI HIPERURISEMIA PADA REMAJA OBES DI SMK NEGERI 1 BITUNG
}

\author{
${ }^{1}$ Prilly Monangin \\ ${ }^{2}$ Aaltje Manampiring \\ ${ }^{2}$ Billy Kepel
}

\author{
${ }^{1}$ Kandidat Skrispi Fakultas Kedokteran Universitas Sam Ratulangi Manado \\ ${ }^{2}$ Bagian Kimia Fakultas Kedokteran Universitas Sam Ratulangi Manado
}

\begin{abstract}
Uric acid is an end product of purine metabolism of substances derived from the rest of the food we eat. Substances contained in any materials purine foods we eat both animals and plants. Some studies show an association between uric acid with hypertension, obesity kidney disease and cardiovasculer disease. The associated factors with the encidance of hyperuricemia is sex, BMI, carbohydrate intake, and intake of purines. This study aimed to determine the prevalence of obesity among adolescents in SMK Negeri 1 Bitung and prevalence of hyperuricemia in obese adolescents at SMK Negeri 1 Bitung. The method was used an observational cross-sectional approach. Data obtained by measuring waist circumference and laboratory examinations are taking blood specimens for examination uric acid levels. From the 100 students representing adolescents were screened by measuring waist circumference, which includes criteria obese students is 24 students (24\%) and nonobese students (76\%). A total of 10 students who met the criteria were examined obese uric acid levels, there was 1 female students (1\%) who had hyperuricemia. As control of the research conducted checks on 10 non-obese students to examine the levels of uric acid, there were 6 students (6\%) who hyperuricemia consisting of 2 boys (2\%) and 4 female students (4\%). The prevalence of obese adolescents in biutng quite high (24\%) and the incidane of hyperuricemia 10 students who meet the criteria and are willing to be obese subjects is 1 students (1\%) and the incidance of hyperuricemia of 10 students who are willing to serve non-obese subjects were 6 students (6\%). It was concluded that tehere wass no association the obesity with hyperuricemia.
\end{abstract}

Keywords: Hyperuricemia, adolescents, central obesity.

\begin{abstract}
Abstrak: Asam urat adalah hasil akhir metabolisme zat purin yang berasal dari sisa makanan yang kita konsumsi. Zat purin terdapat dalam setiap bahan makanan yang kita konsumsi baik hewan maupun tumbuhan. Beberapa studi menunjukkan hubungan antara asam urat dengan hipertensi, obesitas, penyakit ginjal dan penyakit kardiovaskuler. Faktor-faktor yang berhubungan dengan kejadian hiperurisemia adalah jenis kelamin, IMT, asupan karbohidrat dan asupan purin. Penelitian ini bertujuan untuk mengetahui prevalensi obesitas pada remaja di SMK Negeri 1 Bitung dan prevalensi hiperurisemia pada remaja obes di SMK Negeri 1 Bitung. Metode yang digunakan adalah observasional dengan pendekatan cross sectional. Data diperoleh dengan melakukan pengukuran lingkar pinggang dan pemeriksaan laboratorium yaitu pengambilan spesimen darah untuk pemeriksaan kadar asam urat. Dari 100 siswa yang mewakili remaja yang diskrining dengan pengukuran lingkar pinggang, siswa yang termasuk kriteria obes adalah 24 siswa (24\%) dan siswa non obes 76 siswa (76\%). Sebanyak 10 siswa yang memenuhi kriteria obes yang diperiksa kadar asam urat terdapat 1 siswa perempuan (1\%) yang mengalami hiperurisemia. Sebagai kontrol dari penelitian dilakukan pemeriksaan terhadap 10 siswa non obes untuk diperiksa kadar asam urat, terdapat 6 siswa (6\%) yang mengalami hiperurisemia yang terdiri dari 2 siswa laki-laki (2\%) dan 4 siswa perempuan (4\%). Prevalensi remaja obes di kota Bitung cukup tinggi (24\%) dengan kejadian hiperurisemia dari 10 siswa yang memenuhi kriteria obes dan bersedia dijadikan subjek penelitian adalah 1 siswa (1\%) dan kejadian hiperurisemia dari 10 siswa non obes yang bersedia dijadikan subjek penelitian adalah 6 siswa (6\%). Dapat disimpulkan bahwa tidak ada hubungan hiperurisemia dengan obesitas.
\end{abstract}

Kata kunci: Hiperurisemia, remaja, obesitas sentral. 
Secara sederhana obesitas didefinisikan sebagai akumulasi lemak yang berlebihan dan dapat menimbulkan resiko bagi kesehatan. Tingkat obesitas seseorang di ukur dengan menggunakan Indeks Masa Tubuh (IMT) yaitu perbandingan berat $(\mathrm{kg})$ dan kuadrat tinggi $\left(\mathrm{m}^{2}\right)$. Seseorang dengan indeks massa tubu角 30 di kategorikan sebagai obes daæ 25 disebut overweight. Obesitas saat ini menjadi epidemi global, pada 2005 WHO memperkirakan bahwa setidaknya 400 juta orang mengalami obesitas. Di Indonesia dari perkiraan 210 juta penduduk pada tahun 2000, jumlah penduduk yang overweight mencapai 76,7 juta $(17,5 \%)$ dan jumlah pasien obesitas di perkirakan 9,8 juta (4,7\%). Data hasil riskesdas tahun 2007 terdapat 19,1\% kasus obesitas pada penduduk berusia lebih dari 15 tahun. $^{1-4}$ Terjadinya obesitas melibatkan beberapa faktor yaitu faktor genetik, lingkungan, psikis, perkembangan dan aktivitas fisik. Himpunan Studi Obesitas Indonesia memeriksa lebih dari 6000 orang dari hampir seluruh provinsi dan didapatkan angka obesitas dengan IMT $>30 \mathrm{~kg} / \mathrm{m}^{2}$ pada laki-laki sebesar $9,16 \%$ dan pada perempuan $11,02 \%$. Penelitian yang menggunakan ukuran lingkar pinggang sebagai gambaran obesitas abdominal pada laki-laki usia 42-60 tahun dan diikuti perjalanan penyakitnya selama 10 tahun. Hasil menunjukkan lakilaki dengan lingkar pinggang $>90 \mathrm{~cm}$ memiliki peningkatan resiko dua kali lipat terhadap PJK dibanding dengan yang memiliki ukuran lingkar pinggang $<83,5$.,6 Asam urat adalah hasil akhir metabolisme zat purin yang berasal dari sisa makanan yang kita konsumsi. Zat purin terdapat dalam setiap bahan makanan yang kita konsumsi baik hewan maupun tumbuhan. Secara alamiah purin sudah dihasilkan oleh tubuh sebesar 85\%, jadi hanya $15 \%$ purin yang di butuhkan dari asupan makanan. Peningkatan kadar asam urat darah diatas normal disebut hiperurisemia. Hiperurisemia terjadi jika kadar asam urat dalam serum pada laki-laki $>7,0 \mathrm{mg} / \mathrm{dl}$ dan pada perempuan $>6,0 \mathrm{mg} / \mathrm{dl}$. Hiperurisemia bisa terjadi karena peningkatan metabolisme asam urat, penurunan pengeluaran asam urat atau gabungan keduanya. Prevalensi hiperurisemia kira-kira 2,6-47,2 \% yang bervariasi pada berbagai populasi. Beberapa studi juga menunjukkan hubungan antara asam urat dengan hipertensi, obesitas, penyakit ginjal dan penyakit kardiovaskuler. Lebih dari $70 \%$ penderita dengan hiperurisemia mengalami obesitas, lebih dari 50\% dengan hipertensi, 10-25 \% meninggal akibat penyakit ginjal dan sekitar 20\% meninggal akibat komplikasi kardiovaskuler. ${ }^{7-9}$ Terdapat kesamaan antara orang yang mengalami hiperurisemia dan yang obesitas yaitu pola makan yang tidak terkontrol. Dari penelitian di sebutkan bahwa faktor-faktor yang berhubungan dengan kejadian hiperurisemia adalah jenis kelamin, IMT, asupan karbohidrat dan asupan purin. Beberapa penelitian yang menyebutkan bahwa tidak ada hubungan antara hiperurisemia dengan obesitas. ${ }^{10-13}$ Berdasarkan uraian diatas maka penulis merasa perlu melakukan penelitian untuk mengetahui prevalensi hiperurisemia pada remaja obes di SMK Negeri 1 Bitung.

\section{METODE PENELITIAN}

Penelitian ini menggunakan metode observasional dengan pendekatan cross sectional. Penelitian dilakukan pada bulan November-Desember 2011. Pengambilan spesimen darah dilakukan di SMK Negeri 1 Bitung.Analisa spesimen darah dilakukan di Balai Penunjang Pelayanan Kesehatan Dinas Kesehatan Provinsi Sulawesi Utara.Populasi penelitian adalah siswa-siswi di SMK Negeri 1 Bitung. Sampel penelitian adalah siswa-siswi di SMK Negeri 1 yang memenuhi kriteria inklusi: Siswa-siswi yang berusia 15-19 tahun dan dalam keadaan sehat di SMK Negeri 1 Bitung; Siswa-siswi SMK Negeri 1 Bitung yang bersedia untuk dijadikan sampel penelitian, telah berpuasa selama 10-12 jam; Siswa-siswi SMK Negeri 1 Bitung yang bersedia menandatangani surat persetujuan.Penelitian ditujukan pada remaja 15-19 tahun yang sekolah di SMK Negeri 1 Bitung pada bulan NovemberDesember 2011. Penelitian ini dilakukan pada siswa kelas X, XI dan XII yang 
mewakili remaja umur 15-19 tahun di SMK Negeri 1 Bitung. Pada awal penelitian, peneliti terlebih dahulu membuat surat persetujuan penelitian yang ditanda tangani oleh Kepala Dinas Pendidikan kota Bitung. Kemudian surat tersebut diserahkan kepada Kepala Sekolah Menengah Kejuruan Negeri 1 Bitung untuk mendapat izin penelitian di sekolah tersebut. Setelah mendapat izin penelitian, peneliti melakukan sosialisasi kemudian di bagikan informed consent lalu di lakukan skrining atau penyaringan remaja yang obes dan hiperurisemia dengan cara pengukuran lingkar pinggang dan pengambilan darah untuk dilakukan pemeriksaan asam urat. Setelah mendapat izin penelitian, peneliti melakukan sosialisasi kemudian di bagikan informed consent lalu di lakukan skrining atau penyaringan remaja yang obes dan hiperurisemia dengan cara pengukuran lingkar pinggang dan pengambilan darah untuk dilakukan pemeriksaan asam urat.

Penelitian yang dilakukan di SMK Negeri 1 Bitung pada bulan NovemberDesember 2011 terhadap 100 orang siswasiswi yang berusia 10-19 tahun ditemukan 24 orang siswa obes yang terdiri dari 3 siswa laki-laki dan 21 siswa perempuan. Dari 24 orang siswa tersebut diambil 10 orang secara acak yang bersedia untuk dijadikan sampel dan memenuhi prosedur pemeriksaan kadar asam urat dalam darah. Sebagai pembanding atau kontrol dari kasus, juga dilakukan pemeriksaan terhadap 10 orang siswa yang termasuk dalam kategori non-obes. Sesuai dengan prosedur pemeriksaan kadar asam urat harus terlebih dahulu mendapat persetujuan surat informed consent dan melakukan puasa selama 10-12 jam. Data yang di peroleh kemudian dikumpul, diolah secara manual dan komputer, selanjutnya di sajikan dalam bentuk tabel.

\section{HASIL PENELITIAN}

Sebanyak 100 siswa yang mewakili remaja yang diskrining terdapat 13 siswa laki-laki dan 87 siswa perempuan. Melalui pengukuran lingkar pinggang dari 100 siswa tersebut didapatkan 24 siswa yang dapat dikategorikan dalam kriteria obes dan 76 siswa non obes yang terdiri dari laki-laki dan perempuan. Dari 24 siswa yang termasuk dalam kriteria obes terdapat 3 siswa laki-laki dan 21 siswa perempuan. Dari 76 siswa yang non obes terdapat 10 siswa laki-laki dan 66 siswa perempuan. Setelah didapatkan 24 siswa yang dikategorikan dalam kriteria obes dan 76 siswa non obes maka selanjutnya dilakukan penyaringan untuk melakukan pemeriksaan kadar asam urat. Didapatkan 10 siswa yang dapat di kategorikan dalam kriteria obes yang terdiri dari siswa perempuan yang bersedia untuk dijadikan subjek penelitian pemeriksaan kadar asam urat. Dan sebagai kontrol dari penelitian didapatkan 10 siswa non obes yang terdiri dari 5 siswa laki-laki dan 5 siswa perempuan yang bersedia dijadikan subjek penelitian untuk pemeriksaan kadar asam urat darah.

Tabel 1. Prevalensi obes berdasarkan jenis kelamin

\begin{tabular}{lccc}
\hline \multirow{2}{*}{ Jenis Kelamin } & \multicolumn{2}{c}{ Obes } & Total \\
\cline { 2 - 3 } & Ya & Tidak & \\
\hline Laki-laki & 3 & 10 & 13 \\
Perempuan & 21 & 66 & 87 \\
Total & 24 & 76 & 100 \\
\hline
\end{tabular}

Dari Tabel diatas dapat dilihat bahwa 100 siswa yang diskrining dengan pengukuran lingkar pinggang, siswa yang termasuk kriteria obes adalah 24 siswa dengan presentasi sebesar $24 \%$ yang terdiri dari 3 siswa laki-laki dan 21 siswa perempuan. 
Tabel 2. Kadar asam urat pada remaja obes dan remaja non obes

\begin{tabular}{lccc|cccc}
\hline \multicolumn{2}{c}{ Obes } & \multicolumn{5}{c}{ Non Obes } \\
\hline No & Jenis Kelamin & $\begin{array}{c}\text { Lingkar } \\
\text { Pinggang }\end{array}$ & $\begin{array}{c}\text { Kadar } \\
\text { Asam Urat } \\
\text { (mg/dl) }\end{array}$ & No & Jenis Kelamin & $\begin{array}{c}\text { Lingkar } \\
\text { Pinggang }\end{array}$ & $\begin{array}{c}\text { Kadar } \\
\text { Asam } \\
\text { Urat } \\
\text { (mg/dl) }\end{array}$ \\
\hline 1 & Perempuan & 82 & 4,4 & 1 & Perempuan & 72 & 5,9 \\
2 & Perempuan & 83 & 4,8 & 2 & Laki-laki & 77 & 6,2 \\
3 & Perempuan & 81 & 5,8 & 3 & Laki-laki & 67 & 8,0 \\
4 & Perempuan & 84 & 5,1 & 4 & Perempuan & 75 & 9,0 \\
5 & Perempuan & 90 & 5,0 & 5 & Laki-laki & 73 & 5,7 \\
6 & Perempuan & 83 & 5,5 & 6 & Laki-laki & 81 & 6,5 \\
7 & Perempuan & 83 & 4,5 & 7 & Perempuan & 75 & 5,3 \\
8 & Perempuan & 84 & 5,0 & 8 & Perempuan & 69 & 6,0 \\
9 & Perempuan & 81 & 5,2 & 9 & Laki-laki & 67 & 7,2 \\
10 & Perempuan & 82 & 4,5 & 10 & Perempuan & 70 & 6,1 \\
\hline
\end{tabular}

Tabel diatas menunjukkan 10 siswa yang memenuhi kriteria dalam kategori obes dan 10 siswa non obes yang bersedia dijadikan subjek penelitian untuk pemeriksaan kadar asam urat dan melaksanakan puasa selama 10-12 jam sebelum pengambilan darah. Dari 10 siswa yang obes didapatkan siswa yang mengalami hiperurisemia atau kadar asam urat yang melebihi batas normal sebanyak 1 siswa perempuan.Sebagai kontrol atau perbandingan dari penelitian ini, dilakukan juga pengambilan dan pengukuran sampel darah terhadap 10 siswa yang nonobes.Hasil pemeriksaan kadar asam urat dari 10 siswa yang non-obes pada tabel diatas terdapat 6 siswa mengalami hiperurisemia yang terdiri dari 2 siswa laki-laki dan 4 siswa perempuan.

\section{BAHASAN}

Berdasarkan hasil pemeriksaan lingkar pinggang pada 100 siswa didapatkan 24 siswa obes dengan presentasi sebesar $24 \%$ yang terdiri dari 3 siswa laki-laki dengan presentase sebesar 3\% dan 21 siswa perempuan dengan presentasi sebesar $21 \%$. Hal ini dapat dibandingkan dengan data yang diperoleh Ramona Monijung tahun 2011 di Kota Amurang, prevalensi obesitas sebesar 21\% yang terdiri dari $7 \%$ remaja laki-laki dan $14 \%$ remaja perempuan. Hal ini menunjukkan bahwa sebagian besar obesitas dialami oleh perempuan dibandingkan laki-laki. Hasil riset kesehatan dasar (RISKESDAS) 2007 menyatakan prevalensi obesitas umum secara nasional pada penduduk usia $>15$ adalah 19,1\% (8,8 $\%$ BB lebih dan 10,3 \% obes). Secara nasional prevalensi obesitas umum pada laki-laki lebih rendah dibandingkan dengan perempuan pada penduduk usia $>15$ tahun (masing-masing 13,9\% dan 23,8\%). Obesitas sentral dianggap sebagai faktor resiko yang erat kaitannya dengan beberapa penyakit degenaratif. Untuk laki-laki dengan lingkar pinggang diatas $90 \mathrm{~cm}$ atau perempuan dengan lingkar pinggang diatas $80 \mathrm{~cm}$ dinyatakan sebagai obesitas sentral. Prevalensi obesitas sentral pada perempuan (29\%) lebih tinggi dibanding laki-laki (7,7\%). Menurut tipe daerah tampak lebih tinggi di daerah perkotaan (23,6\%) dibandingkan daerah pedesaan $(15,7 \%){ }^{14}$ Prevalensi global telah meningkat drastis di sebagian besar negara selama 20 tahun terakhir, kini terdapat lebih banyak orang yang memiliki berat badan berlebih ketimbang penderita gizi kurang di seluruh dunia. Prevalensi obesitas lebih sering pada kelompok berstatus sosial-ekonomi rendah di negara barat, akan tetapi di beberapa belahan dunia, seperti India, obesitas lebih banyak ditemukan pada kelompok yang 
taraf hidupnya lebih tinggi. Secara umumobesitas meningkat seiring dengan bertambahnya usia, insidensi berat badan berlebih dan obesitas meningkat di kalangan anak-anak dan remaja. Dari segi kesehatan masyarakat, kecenderungan ini mengkhawatirkan karena di iringi oleh peningkatan resiko penyakit yang terkait dengan obesitas. Di Indonesia, seperti halnya di negara maju saat ini telah terjadi berbagai perubahan gaya hidup, terutama pada pola makan. Dengan semakin banyaknya makanan siap saji (fast food) di berbagai tempat dan peningkatan kondisi sisioekonomi masyarakat, maka pola makan masyarakat berubah menuju westernisasi. Asupan makanan yang berlebih dengan kandungan gizi yang kurang seimbang tersebut dapat menjadi pemicu obesitas. Faktor utama yang berperan dalam obesitas antara lain predisposisi genetik, ketidakseimbangan energi, faktor lingkungan, dan faktor sosial ekonomi. Obesitas terjadi karena penumpukan sel lemak yang berlebihan di jaringan adiposa, umumnya ditandai dengan distribusi lemak tubuh regional atau abdominal (obesitas sentral). Produk-produk keluaran sel lemak inilah yang bertanggung jawab terhadap berbagai penyakit, seperti sindrom metabolik, penyakit jantung koroner, dislipidemia, hipertensi, stroke, dan diabetes tipe-2. ${ }^{15,16}$ Hasil penelitian selanjutnya yaitu pemeriksaan kadar asam urat dalam darah telah didapatkan hasil yang berbeda mengenai prevalensi hiperurisemia pada remaja obes di kota Bitung dibandingkan dengan berbagai data penelitian yang ditemukan sebelumnya. Hasil pemeriksaan kadar asam urat dalam darah pada 10 siswa obes yang bersedia untuk dijadikan subjek penelitian didapatkan 1 remaja perempuan yang mengalami hiperurisemia dengan presentase sebesar 1\%. Sebagai kontrol dari penelitian dilakukan juga pemeriksaan kadar asam urat pada 10 siswa non obes, hasil pemeriksaan kadar asam urat dalam darah pada 10 siswa non obes yang bersedia untuk dijadikan subjek penelitian didapatkan sebanyak 6 siswa yang mengalami hiperurisemia dengan presentase sebesar 6\% yang terdiri dari 2 siswa laki-laki dengan presentase sebesar $2 \%$ dan 4 siswa perempuan dengan presentasi $4 \%$.Kejadian yang pasti dari hiperurisemia dan gout di masyarakat pada saat ini belum jelas. Prevalensi hiperurisemia di masyarakat diperkirakan antara 2,3 sampai 17,6\%. Sedangkan prevalensi gout bervariasi antara 1,6 sampai 13,6 per seribu penduduk. Asam urat adalah suatu senyawa nitrogenous yang merupakan produk akhir dari hasil degradasi purin. Sebagian asam urat di produksi di dalam hepar. Purin yang merupakan sumber utama dari asam urat dapat berasal dari tiga sumber yaitu purin dari makanan, perubahan asam nukleat jaringan menjadi nukleotida purin dan sintesis de novo basa purin. Kadar asam urat yang ada dalam serum dipengaruhi oleh beberapa hal seperti kecepatan eksresinya oleh ginjal, usia dan juga jenis kelamin. Asupan yang masuk ke tubuh juga mempengaruhi kadar asam urat dalam darah. Makanan yang mengandung zat purin yang tinggi akan diubah menjadi asam urat. Purin yang tinggi terutama terdapat dalam jeroan, udang, cumi, kerang, kepiting, ikan teri dan lain-lain. Produksi asam urat meningkat juga bisa karena penyakit darah (penyakit sumsum tulang, polisitemia), obat-obatan (alkohol, obat-obat kanker, vitamin B12). Penyebab lainnya adalah obesitas, penyakit kulit (psoriasis), kadar trigliserida yang tinggi.Pada orang dengan kondisi obesitas memiliki kecenderungan mengalami peningkatan kadar asam urat sedangkan pengeluarannya sedikit, karena lemak yang berlebihan dianggap mampu menghambat ekskresi asam urat di ginjal serta meningkatkan resistensi insulin yang mengakibatkan peningkatan reabsorbsi asam urat di ginjal.Oleh karena itu, jagalah agar jangan sampai mengalami kegemukan dengan rutin berolah raga dan memperhatikan asupan makanan sehari-hari. Pada penderita diabetes yang tidak terkontrol dengan baik biasanya terdapat kadar benda-benda keton (hasil buangan metabolisme lemak) yang meninggi. Benda-benda keton yang meninggi akan menyebabkan peningkatan asam urat. Kadar asam urat semakin meningkat seiring dengan pertambahan berat badan dari hewan uji coba. Oleh karena 
hewan coba termasuk obes dan mengalami resistensi insulin oleh karena mutasi pada reseptor leptin, hiperurisemia tidak bisa dijadikan faktor penyebab obesitas pada kondisi yang terjadi pada sampel penelitian. ${ }^{9,10,17}$

\section{SIMPULAN DAN SARAN}

Berdasarkan pada penelitian yang telah dalakukan di SMK Negeri 1 Bitung mengenai Prevalensi Hiperurisemia pada Remaja Obes di SMK Negeri 1 Bitung dapat di ambil kesimpulan bahwa pada penelitian ini prevalensi remaja obes lebih rendah daripada remaja non obes. Penderita obesitas lebih tinggi pada perempuan daripada laki-laki. Prevalensi remaja obes yang mengalami hiperurisemia lebih rendah dibandingkan dengan dengan remaja obes yang tidak mengalami hiperurisemia. Prevalensi remaja non obes yang mengalami hiperurisemia lebih tinggi daripada yang tidak mengalami hiperurisemia. Penderita hiperurisemia pada remaja non obes lebih tinggi pada perempuan di bandingkan pada laki-laki. Berdasarkan hasil penelitian bahwa prevalensi hiperurisemia di SMK Negeri 1 Bitung pada remaja obes hanya sedikit yang mengalami hiperurisemia, namun dibutuhkan tindakan pencegahan dan perbaikan untuk hiperurisemia.

\section{DAFTAR PUSTAKA}

1. World health Organization. Obesity. Available at: http://www.who.int/topics/ obesity/en. Akses 9 november 2011

2. WIKIPEDIA. Epidemiology of Obesity. Available at: //http://Wikipedia.org/wiki/ epidemiology_of_obesity. Akses 9 november 2011.

3. Pamela, R.D. Overweight dan obesitas sebagai suatu resiko penyakit degeneratif. 2010. Available at: http://www.suyoto hospital.com/index.php?option=com conten \& new= article \& id= 115: overweight-danobesitas-sebagai-suatu-resiko-penyakitdegeneratif\&catid= 3 article $\&$ itemid $=2$. Akses 20 november 2011.

4. Ekowaty retnianingsih. Model prediksi prevalensi obesitas pada penduduk umur diatas 15 tahun di Indonesia. 2011. Available at: /inovasiekowati.wordpress. com/2011/02/25/model-prediksi- prevalensi-obesitas-pada-penduduk-umurdiatas-15tahun-di-indonesia/. Akses 9 november 2011.

5. Wikipedia. Obesitas. Available at: id.wikipedia.org/wiki/obesitas. Akses 9 november 2011.

6. Soegih R, Wiramihardja K. Obesitas .FK UNPAD. 2009.

7. Wikipedia. Asam Urat. Available at: id.wikipedia.org/wiki/asamurat. Akses 9 november 2011.

8. Diansyah nor, pratanu Iswanto. Hiperurisemia dan penyakit kardiovaskuler. 2009. Available at: http://arekkardiounair. blogspot.com/2009/07/hiperurisemia-danpenyakit.html. Akses 19 november 2011

9. Hidayat, Rudi. Gout dan Hiperurisemia. 2009. Available at: www.dexamedica.com/images/gout_dan_hiperurisemi a.pdf. Akses 20 november 2011.

10. Darmawan, John. Komplikasi dan kematian dini akibat asam urat. 2008. Available at: www.elitha-eri.net/2008/01/04/komplikasidan-kematian-dini-akibat-asam-urat/. Akses 9 november 2011.

11. Rini setyoningsih. Faktor-faktor yang berhubungan dengan kejadian hiperurisemia pada pasien rawat jalan RSUP Dr. Kariadi Semarang. 2009. Available at: http://eprints.undip.ac.id/25234/. Akses 18 november 2011.

12. Bagus kurniawan. Hubungan hiperurisemia dengan obesitas. available at: http://124.40.250.43/diglib/indeks.php?act= view\&id=8469. Akses 18 november 2011.

13. Dina evariyana. Kegemukan dan hiperurisemia pada warga RW 13 kelurahan Bakti Jaya kecamatan Sukmajaya Depok Jawa Barat tahun 2005. 2008. Available from: http://diglib.unej.ac. id/gd142/gdl.php?mod=browse\&op=read\& id=gdlhub-gdl-grey-2008-dinaeveriy-613.

Akses 19 november 2011.

14. Sofian. AsamUrat..definisi, pencegahan dan pengobatan. 2008. Available at: http://sofia online.com/asam-urat-definisi-pencegahandan-pengobatan. Akses 20 november 2011.

15. RISKESDAS. 2007. Available at: http://www.docstoc.com/docs/19707850/la poran-hasil-riset-kesehatan-dasar(RIKESDAS)-Nasional-2007.

16. Mary Barasi. At a glance Ilmu Gizi. Jakarta: Erlangga. 2009.

17. Biotest. Obesitas. 2011. available at: http://www.biotest.co.id/news.php? Id=T8 $\&$ title $=$ obesitas. 